\title{
The contribution of EMCA to landslide susceptibility mapping in Central Asia
}

\author{
Annamaria Saponaro*, Marco Pilz, Dino Bindi, Stefano Parolai
}

Helmholtz Center Potsdam - German Research Center for Geosciences, Potsdam, Germany

\author{
Article history \\ Received September 19, 2014; accepted October 13, 2014. \\ Subject classification: \\ Earthquake-triggered landslides, Landslide susceptibility, Central Asia.
}

\begin{abstract}
Central Asia is one of the most exposed regions in the world to landslide hazard. The large variability of local geological materials, together with the difficulties in forecasting heavy precipitation locally and in quantifying the level of ground shaking, call for harmonized procedures to better quantify the hazard and the negative impact of slope failures across the Central Asian countries. As a first step towards a quantitative landslide hazard and risk assessment, a landslide susceptibility analysis at regional scale has been carried out, by benefitting of novel seismic hazard outcomes reached in the frame of Earthquake Model Central Asia (EMCA) project. By combining information coming from diverse potential factors, it is possible to detect areas where a potential for landslides exists. Initial results allow the identification of areas that are more susceptible to landslides with a level of accuracy greater than $70 \%$. The presented method is, therefore, capable of supporting land planning activities at the regional scale in places where only scarce data are available.
\end{abstract}

\section{Introduction}

Earthquake-triggered landslides in rock and soil are a major geological hazard in the mountains of Central Asia. The region is located in the Asia-India continental collision zone where the northward-moving Indian Plate indents the Eurasian Plate [Molnar and Tapponnier 1975]. The ongoing collision has resulted in high mountain topography which is subject to active deformation, contemporary faulting and frequent strong earthquakes [Gubin 1962, Burtman and Molnar 1993, Pavlis et al. 1997, Sidorova 1997, Perov and Budarina 2000], that combine to give rise to widespread landslide phenomena including massive rock slope failures in both the Pamir and Tien Shan Mountains [e.g., Gaziev 1984, Havenith et al. 1999, Abdrakhmatov and Strom 2006, Havenith et al. 2006, Strom and Korup 2006, Havenith and Bourdeau 2010]. In addition, much of the topography of the region is mantled by weakly consolidated sediments, being particularly prone to flowslides triggered by seismic shaking and/or heavy rainfall [Gubin 1962, Ishihara 1989, Ishihara 2012].

Within the last 60 years, Central Asia has seen a multiplication of its population from 18 million in 1951 to more than 53 million in 2010 [Lutz 2010]. The increase of population in combination with the expansion of urban settlements towards landslide-prone slopes further contribute to the destructive impact of landslides due to relatively little investment in understanding the hazards and risks and an added lack of appropriate resources [Rosenfeld 1994, Petley 2012]. Already in the past compelling evidence of the destructive power of such landslides in Central Asia has been shown (Figure 1): landslides, mudslides and debris flows caused an extensive number of casualties (Table 1) during, e.g., the $1911 \mathrm{M}=8.2 \mathrm{Kemin}$ earthquake in the Kazakh/Kyrgyz border region, the $1949 \mathrm{M}=7.4$ Khait and the $1989 \mathrm{M}=5.5$ Gissar earthquakes in Tajikistan, the $1946 \mathrm{M}=7.5$ Chatkal and the $1992 \mathrm{M}=7.3 \mathrm{Su}-$ usamyr earthquakes in Kyrgyzstan. Besides, the 1911 $\mathrm{M}=7.6$ Sarez earthquake in Tajikistan triggered a massive landslide, blocking the Murgab river and forming the tallest river dam in the world. Additionally, there are a multitude of landslides around the Fergana Valley, which straddles Uzbekistan, Kyrgyzstan and Tajikistan. Since this region is quite densely inhabited almost every year landslides lead to damage of settlements and infrastructure and loss of human lives. Here and elsewhere, landslides can further trigger other transboundary hazards, such as lake outburst floods and the release of toxic and radioactive substances into river basins (particularly in the Mailuu-Suu area, north of the Fergana Valley), with the potential to adversely impact a significant number of people.

During Soviet Union times several programs have been developed to deal with the high level of landslide hazard. Already as early as 1924, the Soviet government set up a special commission to direct landslide control 


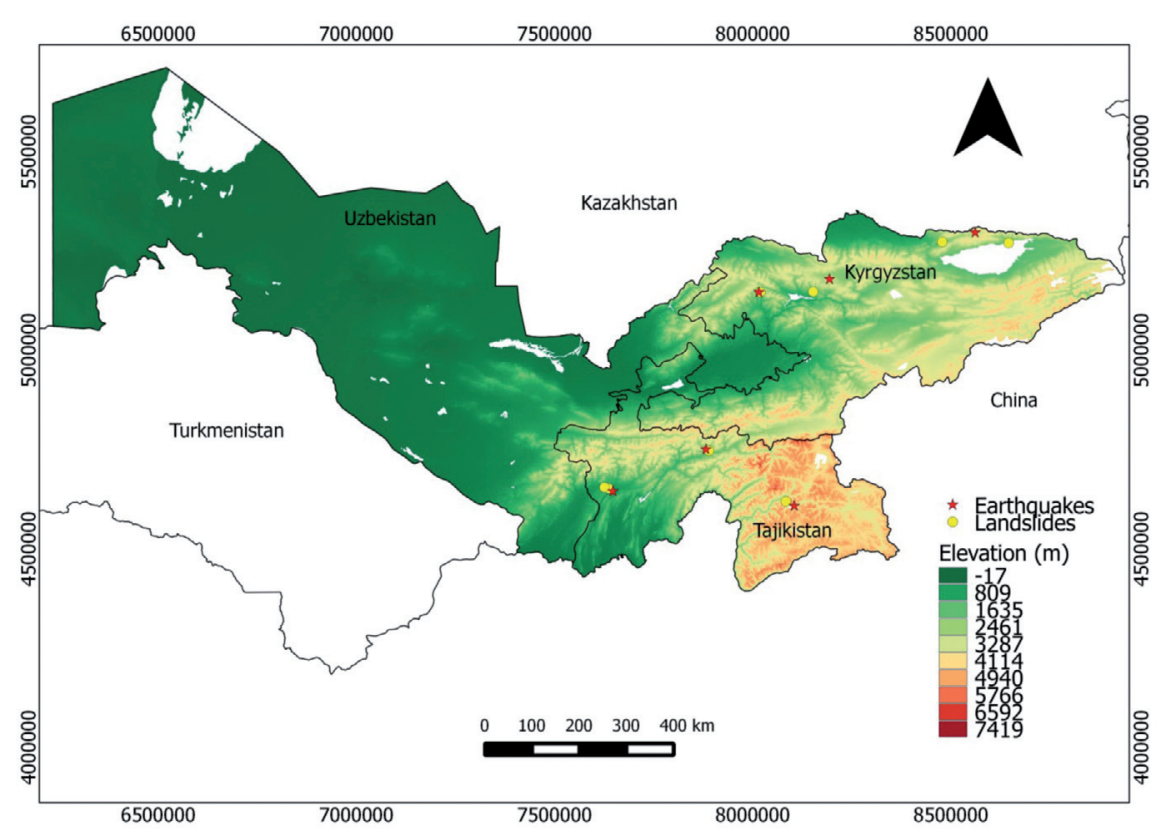

Figure 1. Location map of the study area and some among the strongest past earthquakes and seismically-induced landslides. In particular, the 1911 Sarez (Tajikistan), the 1911 Kemin (Kyrgyzstan), the 1946 Chatkal (Kyrgyzstan), the 1949 Khait (Tajikistan), the Gissar (Tajikistan), and the 1992 Suusamyr (Kyrgyzstan) earthquakes are known to have triggered the 1911 Usoi (Tajikistan), the 1911 Ananievo and Kaindy (Kyrgyzstan), the 1946 Chatkal (Kyrzgystan), the 1949 Khait (Tajikistan), the 1989 Sharora and Okuli-bolo (Tajikistan), the 1992 Belaldy (Kyrgyzstan) landslides, respectively.

measures along the south coast of the Crimea [Sheko 1983]. Over the next 40 years, landslide observation stations were created in many parts of the Soviet Union. Regular monitoring of endangered areas was conducted from the 1960s until the break-up of the Soviet Union at the beginning of the 1990s. These activities also included extensive field-based mapping of single landslides as well as detailed engineering-geological investigations and their relationships to ground water conditions and precipitation, resulting in a good understanding of local slope instabilities. The main goal of these investigations had been the timely warning of the population and, if necessary, their evacuation and resettlement. Based on a 1978 decree of the Soviet Council of Ministers and coordinated by the State Committee on science and technology, homogeneous landslide hazard maps have been published for those areas of high landslide risk which had been of greatest importance for the Soviet economy.

However, after the fall of the Soviet Union in 1991, the possibilities for landslide investigations and monitoring are drastically reduced. Even in Central Asian countries such as Kazakhstan, that have greater resources to devote to hazard analysis, landslide surveys remain underfunded and adequate observation posts are lacking. Furthermore, significant parts of the al-

\begin{tabular}{|c|c|c|c|c|c|}
\hline Name & Location & Date & Volume & Trigger & Number of fatalities \\
\hline Usoi landslide & Tajikistan & 1911 & 2.2 bilion $\mathrm{m}^{3}$ & $\begin{array}{c}\text { Sarez } \\
\text { earthquake }\end{array}$ & 54 people \\
\hline $\begin{array}{l}\text { Kaindy, Ananevo } \\
\text { rock avalanches }\end{array}$ & Kyrgyzstan & 1911 & 15 million $\mathrm{m}^{3}$ both & $\begin{array}{c}\text { Kemin } \\
\text { earthquake }\end{array}$ & 38,0 people \\
\hline Chatkal & Kyrgyzstan & 1946 & 15 million $\mathrm{m}^{3}$ & $\begin{array}{c}\text { Chatkal } \\
\text { Earthquake }\end{array}$ & NA \\
\hline $\begin{array}{c}\text { Khait } \\
\text { rock avalance }\end{array}$ & Tajikistan & 1949 & 75 million $\mathrm{m}^{3}$ & $\begin{array}{c}\text { Khait } \\
\text { earthquake }\end{array}$ & 7200 people \\
\hline $\begin{array}{l}\text { Sharora landslide, } \\
\text { Okuli-bolo mudslide }\end{array}$ & Takijistan & 1989 & $\begin{array}{l}5 \text { million } \mathrm{m}^{3} \text {, } \\
40 \text { milion } \mathrm{m}^{3}\end{array}$ & $\begin{array}{c}\text { Gissar } \\
\text { earthquake }\end{array}$ & 200,70 people \\
\hline Belaldy rockslide & Kyrgyzstan & 1992 & 40 million $\mathrm{m}^{3}$ & $\begin{array}{l}\text { Suusamyr } \\
\text { earthquake }\end{array}$ & 35 people \\
\hline
\end{tabular}

Table 1. List of the largest historical earthquake-induced landslides in Central Asia. 
ready existing data (e.g., maps and reports) are not available anymore or their use is limited because of the loss of accompanying information related to methodology and data sources. Thus, the available landslide hazard and risk analysis in Central Asia is outdated and there is the ultimate need of an updated analysis.

As landslides exist in nature and, in many cases, cannot be prevented it is highly recommendable to decrease their impact and consequences by appropriate hazard mapping and by reducing the exposure and the vulnerability to natural hazards. With the appropriate preventative measures, significant loss of life and economic damage could be avoided. Nadim et al. [2006] assessed landslide occurrence probabilities worldwide on the basis of morphological, geological, meteorological and seismological data. They clearly showed that all landslide hotspots are located in seismically active mountain ranges. However, their analyses suffered from significant shortcomings in the quality and resolution of the available global data sets as well as heterogeneous data.

To this regard, studies carried out in the Earthquake Model Central Asia (EMCA) project can contribute to harmonized procedures to better quantify the hazard and the negative impact of slope failures across Central Asian countries. By exploiting new advances in Geographic Information System (GIS) technology, together with concepts from Bayesian statistics, and promoting the use of open-source tools, it is possible to identify areas where the potential for landslide activation exists. Since an inventory of past landslides in the area is currently missing, the evaluation of landslide susceptibility with limited background information constitutes a constant challenge. The presented method is, therefore, capable of supporting land planning activities at the regional scale in places where only scarce data are available. Thereon, we will give an overview on the investigation of landslide susceptibility and related contributing factors in Kyrgyzstan, Tajikistan and Uzbekistan. Topographic and tectonic causative factors are selected and weights for different categories of these factors are statistically determined for the preparation of landslide susceptibility maps for Central Asian countries.

\section{Data}

For landslide susceptibility analysis, factors considered among the most influential to slope failures occurrences in Central Asia are taken into account. In particular, slope gradient, slope aspect, profile curvature, geology, distance from faults, and seismic intensity are selected. An inventory of past landslides in Kyrgyzstan is compiled and, therefore, used as a reference dataset. Slope gradient, slope aspect and profile curvature for
Kyrgyzstan, Tajikistan and Uzbekistan are derived from the NASA released Shuttle Radar Topographic Mission digital elevation model, with a spatial resolution of 81.7 $\mathrm{m}$ [SRTM 2004]. Geology, distance from faults and seismic intensity maps covering the territories of Kyrgyzstan, Tajikistan and Uzbekistan are digitized and hence converted into raster format with a cell-size equivalent to the SRTM digital elevation model.

\subsection{Landslide locations}

A landslide inventory represents an essential ingredient in order to carry out landslide hazard analysis at the regional scale [Guzzetti et al. 1999]. It helps in identifying locations of previous landslides in order to be able to predict future failures. For the purposes of this study, we considered only one type of mass movement, i.e., landslides occurring in soft materials. A selection of landslide sites is defined on the basis of published information [Kalmetieva et al. 2009], and their distribution is mapped as point locations.

\subsection{Topographic factors: slope gradient, slope aspect} and profile curvature

The stability of a slope is known to be highly dependent upon the slope angle and its material properties [Terzaghi and Peck 1967]. The slope is presented in degrees ranging from $0^{\circ}$ to $88^{\circ}$ and divided into four bins with approximately the same number of features (quantile classification), $0^{\circ}-6.6^{\circ}, 6.6^{\circ}-16.6^{\circ}, 16.6^{\circ}-27.5^{\circ}$, $>27.5^{\circ}$.

Defined as the direction of maximum slope of the terrain surface, slope aspect is typically taken into consideration, although in some cases its importance has been questioned [Guzzetti et al. 1999]. For the selected areas, a classification based on azimuth being divided into eight bins, North, North-East, East, South-Est, South, South-West, West, North-West, has been carried out.

Curvature represents one of the topographic attributes which are also commonly included in a landslide susceptibility analysis [Alalew et al. 2004]. In particular, the profile curvature - defined as the second derivative of the slope with respect to the maximum steepness direction - may help in understanding patterns of flows acceleration and deceleration, and therefore, erosion and deposition. For the selected area, profile curvature values have been classified (quantile classification) into four bins, -0.02507 to $-0.00101,-0.00101$ to $-0.00005,-0.00005$ to $0.00095,0.00095$ to 0.01891 .

\subsection{Geo-tectonic factors: geology and distance from faults}

Lithology plays an important role in landslide susceptibility studies because different geological units have different slope failure behaviours. For example, 
landslides in loess materials have occurred in Uzbekistan, while landslide-prone slopes in cretaceous rocks may be found in Kyrgyzstan. For our study, geological information is obtained from "The Geological Map of Central Asia and Adjacent Areas" [Tingdong et al. 2008], scaled 1:2,500,000; overall, the study area is covered by a range of different sedimentary formations, mostly dated to the Quaternary, Neogene, Paleogene, Cretaceous, Jurassic, and Triassic. Igneous rocks related to the Palaeozoic epoch are also present.

Based on this information, stratigraphic units are digitised and accordingly classified into Paleozoic, Mesozoic and Cenozoic units.

The presence of major lineaments is among the important factors governing the stability of slopes [Varnes 1984]. Tectonic structures form zones of weakness in rocks and might accelerate the process of slope failures. Central Asia is covered by a large number of active faults (e.g., Talas-Fergana fault). For our analysis, fault lines were derived from the 1:2,500,000 scale geology map and four-buffer zone maps (less than $1 \mathrm{~km}, 1$ to $5 \mathrm{~km}$, 5 to $10 \mathrm{~km}$, greater than $10 \mathrm{~km}$ ) were prepared in GIS.

\subsection{Trigger mechanism: seismic intensity}

As the study area is widely and strongly affected by earthquakes, it is necessary to take seismic ground shaking, expressed through the observed macro-seismic intensity (MSK 64), into account as a triggering factor for landslides. Within the EMCA project, Bindi et al. [2012] carried out an uniform assessment of the seismic hazard in Central Asia mainly guided by the observed seismic histories without any a-priori assumption on seismic zonation or on the model of time recurrence. The application of such an approach to cross-border catalogues and considering intensity prediction equations developed for the investigated area [Bindi et al. 2011], allowed to obtain a systematic and homogeneous evaluation of the hazard as well as the evaluation of the probability of exceedance of any given intensity value over a fixed exposure time over the entire analyzed area of different Central Asian countries.

For the territory of Kyrgyzstan and Tajikistan, their studies returned intensities of VIII and IX as expected in the future; for Uzbekistan, an intensity of VIII is expected. The main advantage of this approach is a step towards a homogenized and updated seismic input.

\section{Method}

In this study, the Weights-of-Evidence method is used for generating a landslide susceptibility map. The Weights-of-Evidence method is a data-driven Bayesian quantitative method used to combine evidences in support of a hypothesis [Bonham-Carter 1994].
The method offers a flexible way of testing the importance of various input factors to the potential of slope failure, providing a simple statistical and straightforward tool that allows the calculated weights to be interpreted. Specifically, the influence of landslide potential factors (evidence) on the occurrence of landslides themselves (hypothesis) is assessed. Weights for each landslide causative factor are calculated based on the presence or absence of landslides within the study area.

Suppose that a landslide potential factor occurs in the studied area, and that a number of known landslides occur preferentially within the factor, it is possible to indicate the probability of finding a landslide given the presence $(F)$ or the absence $(\bar{F})$ of a factor, through the definition of conditional probabilities:

$$
\begin{gathered}
P\{L \mid F\}=\frac{P\{L \cap F\}}{P\{F\}}=P\{L\} \frac{P\{F \mid L\}}{P\{F\}} \\
P\{L \mid \bar{F}\}=\frac{P\{L \cap \bar{F}\}}{P\{\bar{F}\}}=P\{L\} \frac{P\{\bar{F} \mid L\}}{P\{\bar{F}\}},
\end{gathered}
$$

where $P\{F \mid L\}$ and $P\{\bar{F} \mid L\}$ are the conditional probabilities of being and not being within the factor, given the presence of a landslide.

The weights for a landslide potential factor are defined as:

$$
\begin{aligned}
& W^{+}=\ln \frac{P\{F \mid L\}}{P\{F \mid \bar{L}\}} \\
& W^{-}=\ln \frac{P\{\bar{F} \mid L\}}{P\{\bar{F} \mid \bar{L}\}} .
\end{aligned}
$$

The difference between positive and negative weights is known as the weight contrast $\left(C=W^{+}-W^{-}\right)$ and provides a useful measure of the overall spatial correlation between a certain class of factor and the occurrence of landslides [Bonham-Carter 1994]. A positive $C$ indicates that the causative factor is present at the landslide location, and its magnitude is a measure of the positive correlation between the presence of the causative factor and landslides. On the other hand, a negative $C$ is used to assess the importance of the absence of the factor in landslide occurrence. Factors with contrast values around 0 have no significant connection with the occurrence of landslides.

In Weights-of-Evidence modelling, it is typically assumed that landslide potential factors are conditionally independent with respect to landslide occurrences. A detailed description of the methodology may be found on our previous work [Saponaro et al. 2014]. 


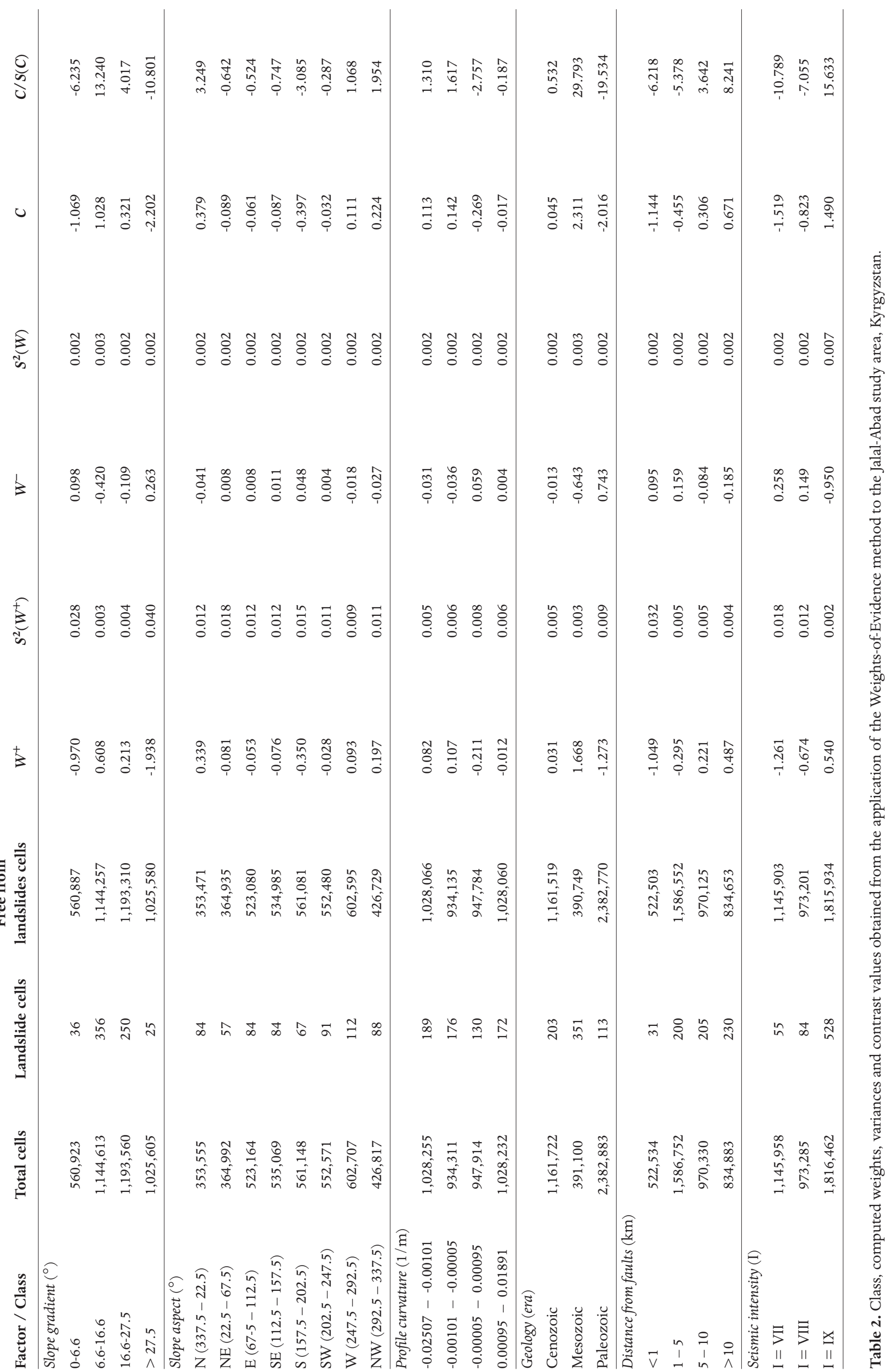




\section{Landslide susceptibility results in Central Asia and discussion}

This section examines where landslides are preferentially triggered by earthquakes within seismically active mountain belts with respect to geomorphological, geological, structural and seismo-tectonic factors.

Weights' calculation has been carried out in the Jalal-Abad district in Kyrgyzstan, where the distribution of landslide factors values is representative of existing relationships for the entire country of Kyrgyzstan. A landslide sample of 1347 locations is used. Specifically, $50 \%$ of the total number of locations are randomly selected in the study areas, and then used as the "training dataset" to calibrate the method. The remaining $50 \%$ of locations are used as the "test dataset" for validating results. The "training dataset" of landslides is overlaid with each landslide potential factor to calculate weights and the statistical parameters representative of existent spatial relationships, shown in Table 2. As can be seen, the most noteworthy classes of parameters with a positive impact on slope instability are: slope gradient $6^{\circ}-16.6^{\circ}$, northfacing slope aspect, mesozoic-aged lithologies, distance from faults greater than $10 \mathrm{~km}$, and seismic intensity values (MSK 64) equal to IX. Furthermore, the highest contrasts $(C / S(C))$ values are found for the geology factor, while lowest ones are for slope aspect.

Thus, landslide factor maps are re-classified on the basis of most stable and unstable classes of factors. By combining previously calculated contrast values with re-classified factors maps, a landslide susceptibility zonation map has been calculated based on:

$$
L S I=\sum_{j=1}^{n} C_{i j}
$$

where LSI indicates a Landslide Susceptibility Index and $C_{i j}$ represents the contrast for the $i$-th bin of the $j$ th factor.

The validity and accuracy of landslide susceptibility maps are typically ascertained with the help of success- and prediction-rate curves in combination with the area under the curves [Chung and Fabbri 2003]. The curves provide information about the relationship between the percentage of area identified as being landslide susceptible and the actual landslide occurrences. Landslide susceptibility results are hence cross-tabulated with landslide locations and presented as a cumulative frequency diagram. When comparing landslide test dataset with landslide susceptibility maps, $66.119 \%$ of landslides are found in the $20 \%$ of highest susceptibility classes, with an accuracy value equal to 0.801 (Figure 2).

In order to present a cross-border landslide susceptibility map for the territories of Kyrgyzstan, Tajikistan and Uzbekistan, landslide factors are re-classified and weighted, following the above described procedure. In particular, values are normalized and classified into 10 equal-interval classes, ranging from 0.016 to 0.971 (Figure 3).

Based on landslide susceptibility results in Kyrgyzstan, high LSI levels are present in the southern region, precisely along the eastern border of Fergana valley, where slope values mostly range from $0.0^{\circ}$ to $16.6^{\circ}$, and the majority of past landslides are also distributed. In addition, high landslide susceptibility are recognized across the Jalal-Abad and the Naryn regions, though the lack of landslide observations. This latter result might indicate the potential for landslide activation and, therefore, serve as input when estimating landslide risk.

A general low level of landslide susceptibility can be observed for almost the entire territory of Uzbekistan. This outcome is plausible given the presence of a conspicuous flat and desert area. Exceptions are represented by the Tashkent and the Buhkara provinces which are characterized by high and medium landslide susceptibility, respectively (Figure 3). In addition, evidences of past slope failures in the Tashkent region provide credit to the calculated susceptibility level. With regard to the Tajik territory, it can be seen that the eastern region is characterized by a larger potential to slope failures than the western one, in agreement with expected higher seismic intensity values. In particular, high levels of landslide susceptibility are expected in the central districts of Tojikobod and Nurobod, in the proximity to the devastating 1949 Khait landslide (Figure 3).

It has to be remarked that the distribution of geological materials is not uniform throughout Central Asian countries. For example, a relatively lower level of landslide susceptibility is found in Tajikistan with respect to Kyrgyzstan. In fact, our proposed susceptibility

\section{ROC Curves - Test Dataset}

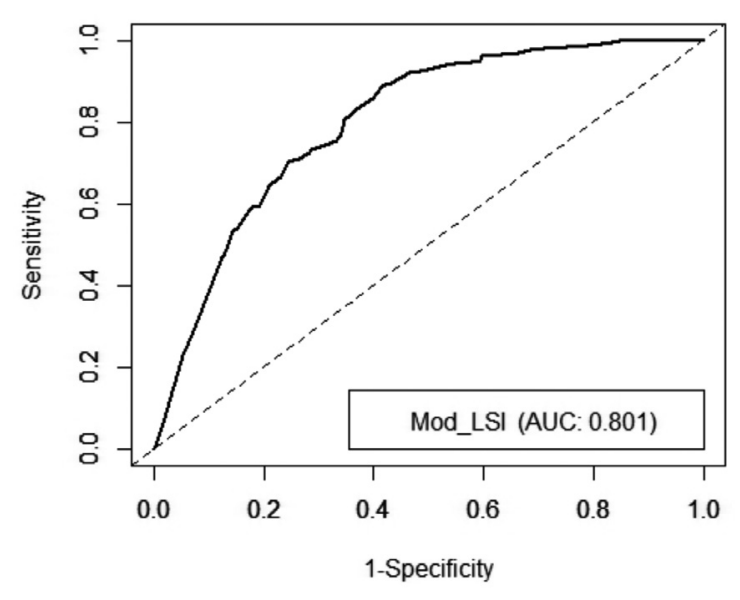

Figure 2. Accuracy assessment of landslide susceptibility model for the test database. 


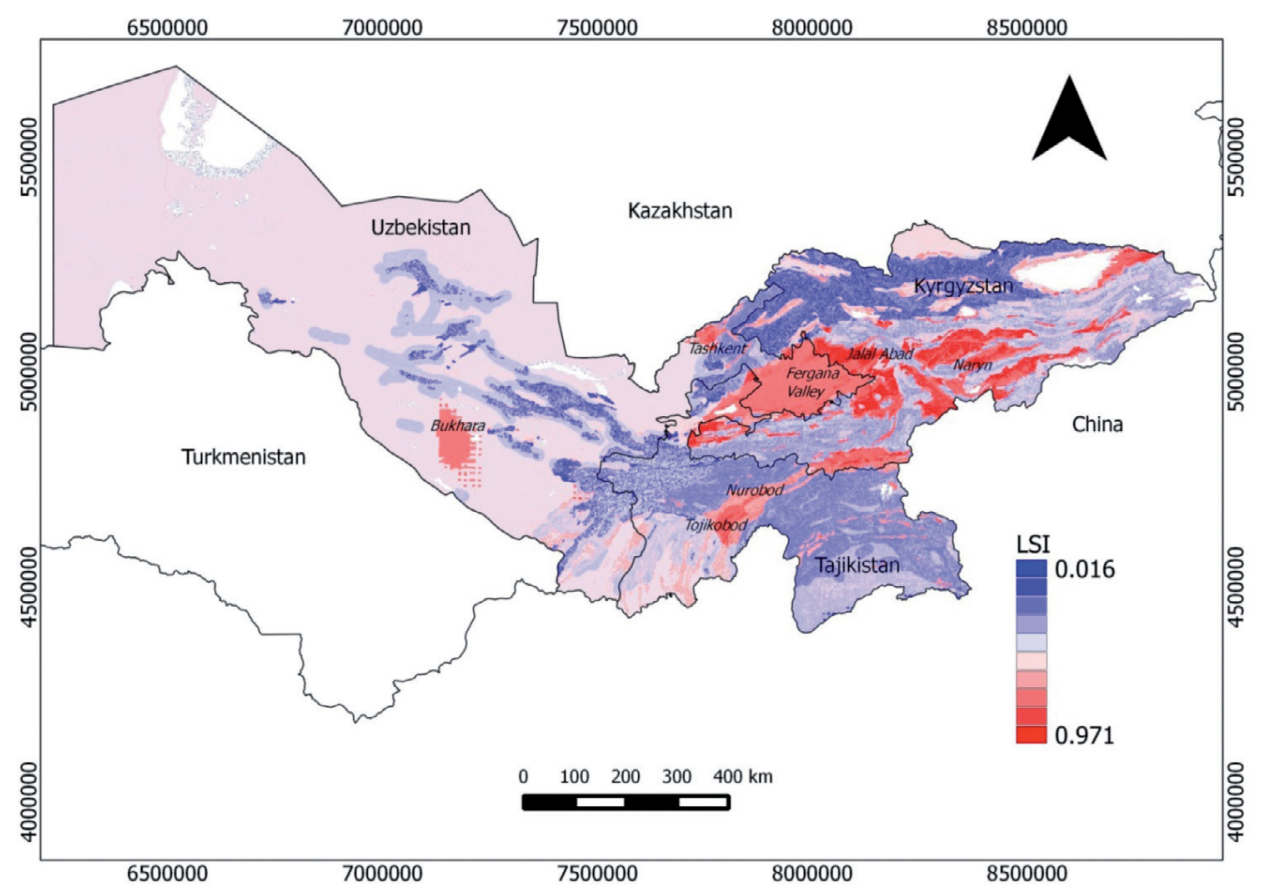

Figure 3. Landslide Susceptibility Index (LSI) map for Kyrgyzstan, Tajikistan and Uzbekistan calculated with respect to slope gradient, slope aspect, profile curvature, geology, distance from faults, and seismic intensity factors. Normalized susceptibility values are shown.

model entitled Mesozoic rocks as the most prone to landslides. However, in Tajikistan the majority of rocks are Paleozoic materials (in particular fractured igneous rocks) that, based on the calibrated model, are classified as "not influent".

Additionally, the widespread presence of loess lithology both in Tajikistan and Uzbekistan should not be underestimated, considering connections to previous slope failures [Evans et al. 2009, Niyazov and Nurtaev 2013]. The fact that both fractured igneous and loess materials have not been explicitly addressed in the analysis might reflect the relatively low susceptibility level found in these countries.

\section{Conclusions}

Central Asia is one of the most challenging places in the world where various natural hazards can heavily injury populations and resources. Among these hazards, landslides pose a serious threat to human life and human facilities. A fundamental step for minimizing landslide risk is represented by the preparation of a susceptibility map. Specifically, the map allows the identification of areas currently free of landslides with a potential for future slope instability. Consequently, such a map can be used as a tool to support disaster management and planning activities at the regional level.

Due to remote conditions characterizing Central Asia, data are not easily accessible, or may be affected by different sources of uncertainty. To this regard, studies conducted within the EMCA project provide harmonized procedures to better quantify the hazard and the negative impact of slope failures across Central Asian countries. In particular, thanks to the hazard analyses carried out in the frame of EMCA, we presented an approach to evaluate the potential to seismically-induced landslides using statistical relationships between past landslides and the most significant seismotectonic, geological and morphological factors in Central Asia countries. The Bayesian-based method is initially calibrated and cross-validated with an independent dataset in Kyrgyzstan [Saponaro et al. 2014], providing us with a landslide susceptibility model having an accuracy level greater than $70 \%$. This level allows us to consider the model sufficiently reliable for planning purposes. Afterwards, due to uniformity in geomorphological and tectonic factors characterizing all Central Asian countries, an extension of the model to the territories of Uzbekistan and Tajikistan is carried out.

As part of future work, we plan the installation of seismic strong motion networks, together with the development of early warning systems in case of a potential landslide-inducing earthquake occurrence. Besides, a more detailed investigation of existing relationships between quaternary rocks (in particular loess) and slope failures will provide specific insight for landslide susceptibility in Tajikistan and Uzbekistan. For this reason, a more detailed inventory of past landslides in under construction.

The present work offers the unique value of providing the first attempts of transnational landslide susceptibility assessment, in which it is possible to identify areas with a potential for future seismically-induced slope instability. 
Acknowledgements. This research presented in this paper has been carried out under the Tien Shan-Pamir Monitoring Program (TIPTIMON) project, with the support of Earthquake Model Central Asia (EMCA) project. We thank U. Borchert and A. Motschmann for helping with data digitization, and the Central Asian Institute for Applied Geosciences (CAIAG) for providing the landslide data.

\section{References}

Abdrakhmatov, K., and A. Strom (2006). Dissected rockslide and rock avalanche deposits; Tien Shan, Kyrgyzstan, In: S.G. Evans, G. Scarascia Mugnozza, A. Strom and R.L. Hermanns (eds.), Landslides from massive rock slope failure, Springer, Netherlands, 551-570.

Alalew L., H. Yamagishi and N. Ugawa (2004). Landslide susceptibility mapping using GIS-based weighted linear combination the case of Tsugawa area of Agano River, Niigata Prefecture Japan, Landslides, 1, 73-81.

Bindi, D., S. Parolai, A. Oth, K. Abdrakhmatov, A. Muraliev and J. Zschau (2011). Intensity prediction equations for Central Asia, Geophys. J. Int., 187, 327-337.

Bindi, D., K. Abdrakhmatov, S. Parolai, M. Mucciarelli, G. Grünthal, A. Ischuk, N. Mikhailova and J. Zschau (2012). Seismic hazard assessment in Central Asia: Outcomes from a site approach, Soil Dyn. Earthq. Eng., 37, 84-91.

Bonham-Carter, G.F. (1994). Geographic Information Systems for Geoscientists: modelling with GIS Computer methods in the geosciences, Pergamon Press, Oxford, vol. 13, 398 pp.

Burtman, V.S., and P. Molnar (1993). Geological and geophysical evidence for deep subduction of continental crust beneath the Pamir, Geol. Soc. Am., 281, 1-76.

Chung, C.J.H., and A.G. Fabbri (2003). Validation of Spatial Prediction Models for Landslide Hazard Mapping, Nat. Hazards, 30, 451-472.

Evans, S.G., N.J. Roberts, A. Ischuk, K.B. Delaney, G. Morozova and O. Tutubalina (2009). Landslides triggered by the 1949 Khait earthquake, Tajikistan, and associated loss of life, Eng. Geol., 109, 195-212.

Gaziev, E. (1984). Study of the Usoi landslide in Pamir, Proc. 4th Int. Symp. on Landslides, 1, 511-514.

Gubin, I.E. (1962). Seismicity and geological structures of Central Asia, Studia Geophysica et Geodaetica, 6, 410-412.

Guzzetti, F., A. Carrara, M. Cardinali and P. Reichenbach (1999). Landslide hazard evaluation: a review of current techniques and their application in a multi-scale study Central Italy, Geomorphology, 31, 181-216.

Havenith, H.B., A. Strom, D. Jongmans, A. Abdrakhmatov, D. Delvaux and P. Tréfois (1999). Seismic trig- gering of landslides, Part A: Field evidence from the Northern Tien Shan, Nat. Haz. Earth Sys. Sc., 3, 135-149.

Havenith, H.B., I. Torgoev, A. Meleshko, Y. Alioshin, A. Torgoev and G. Danneels (2006). Landslides in the Mailuu-Suu Valley, Kyrgyzstan - hazards and impacts, Landslides, 3, 137-147.

Havenith, H.B., and C. Bourdeau (2010). Earthquakeinduced hazards in mountain regions: a review of case histories from Central Asia - an inaugural lecture to the society, Geologica Belgica, 13, 137-152.

Ishihara, K. (1989). Liquefaction-induced landslide and debris flow in Tajikistan, USSR, Landslide News, 3, 6-7.

Ishihara, K. (2012). Performances of Rockfill Dams and Deep-Seated Landslides During Earthquakes, In: M.A. Sakr and A. Ansal (eds.), Special Topics in Earthquake Geotechnical Engineering, Springer, Netherlands, 273-314.

Kalmetieva, Z.A., A.V. Mikolaichuk, B.D. Moldobekov, A.V. Meleshko, M.M. Janaev and A.V. Zubovich (2009). Atlas of Earthquakes in Kyrgyzstan edited by Central-Asian Institute for Applied Geosciences and United Nations, UNISRD, Bishkek, Central Asia.

Lutz, W. (2010). Emerging population issues in Eastern Europe and Central Asia. Research Gaps on Demographic Trends, Human Capital and Climate Change, UNFPA, New York, USA.

Molnar, P., and P. Tapponnier (1975). Cenozoic tectonics of Asia: effects of a continental collision, Science, 189, 419-426.

Nadim, F., O. Kjekstad, P. Peduzzi, C. Herold and C. Jaedicke (2006). Global landslide and avalanche hotspots, Landslides, 3, 159-173.

Niyazov, R., and B. Nurtaev (2013). Modern Seismogenic Landslides Caused by the Pamir-Hindu Kush Earthquakes and Their Consequences in Central Asia, In: C. Margottini, P. Canuti and K. Sassa (eds), Landslide Science and Practice, Springer-Verlag Berlin Heidelberg, 343-348.

Pavlis, T.L., M.W. Hamburger and G.L. Pavlis (1997). Erosional processes as a control on the structural evolution of an actively deforming fold and thrust belt: An example from the Pamir Tien Shan region, Central Asia, Tectonics, 16, 810-822.

Perov, V.F., and O.I. Budarina (2000). Mudflow hazard assessment for the Russian Federation, In: G.F. Wieczorek and N.D. Naeser (eds.), Debris-flow hazards mitigation: mechanics, prediction, and assessment, Balkema, Rotterdam, Netherlands, 489-494.

Petley, D. (2012). Global Patterns of loss of life from landslides, Geology, 40, 927-930. 
Rosenfeld, C. (1994). The geomorphological dimensions of natural disasters, Geomorphology, 10, 27-36.

Saponaro, A., M. Pilz, M. Wieland, D. Bindi, B. Moldobekov and S. Parolai (2014 online). Landslide susceptibility analysis in data-scarce regions: the case of Kyrgyzstan, Bull. Eng. Geol. Environ.; doi:10.10 07/s10064-014-0709-2.

Sheko, A.I. (1983). Landslides and Mudflows - Reports of the Alma-Ata International Seminar, Moscow, Centre of International Projects, GKNT.

Sidorova, T.L. (1997). Potential changes of mudflow phenomena due to global warming, In: D. Rickemann and C.L. Chen (eds.), Debris-flow hazards mitigation: mechanics, prediction, and assessment, Balkema, Rotterdam, Netherlands, 540-549.

SRTM Shuttle Radar Topography Mission (2004). SRTM digital topographic data US Geological Survey's EROS Data Center; URL: ftp:/ / e0mss21uecsn asagov/srtm/ (2004-11-12).

Strom, A.L., and O. Korup (2006). Extremely large rockslides and rock avalanches in the Tien Shan Mountains, Kyrgyzstan, Landslides, 3, 125-136.

Terzaghi, K., and R.B. Peck (1967). Soil mechanics in engineering practice, Wiley and Sons, $752 \mathrm{pp}$.

Tingdong, L., B.S. Ujkenov, B.C. Kim, O. Tomurtogoo, O.V. Petrov and S.I. Strelnikov (2008). Geological map of Central Asia and Adjacent Areas ed. by Geological Publishing House, Beijing, China.

Varnes, J.D. (1984). IAEG Commission on Landslides and Other Mass Movements, Landslide hazard zonation: a review of principles and practice, The UNESCO Press, Paris, 63 pp.

Corresponding author: Annamaria Saponaro,

Helmholtz Center Potsdam - German Research Center for

Geosciences, Potsdam, Germany; email: asapon@gfz-potsdam.de. 